\title{
Original article (short paper) \\ Semi-rigid brace and taping decrease variability of the ankle joint position sense
}

\author{
Márcia Barbanera \\ Flávia de Andrade e Souza Mazuchi \\ José Paulo Berretta Batista \\ Janaina de Moura Ultremare \\ Juliana da Silva Iwashita \\ São Judas Tadeu University, São Paulo, Brazil \\ Ulysses Fernandes Ervilha \\ University of São Paulo, São Paulo, Brazil
}

\begin{abstract}
The present study investigated the effect of taping and the semi-rigid ankle brace on ankle joint position sense. Sixteen healthy women ( $20.8 \pm 2.3$ years old $)$ actively placed the ankle in a target position. The experimental conditions were: 1) wearing no orthosis device, 2) using semi-rigid brace, and 3) wearing ankle taping. Absolute error $(\mathrm{AE})$ and variable error $(\mathrm{VE})$ were calculated to obtain the joint position sense. We found an interaction effect between condition and target angle at $15^{\circ}$ of plantar flexion for the variable VE, which showed smaller errors during the use of taping and semi-rigid brace. In conclusion, the use of ankle joint orthoses, whether taping or semi-rigid brace, decrease the variability of the position sense at $15^{\circ}$ of plantar flexion, potentially decreasing ankle sprains occurrence.
\end{abstract}

Keywords: position sense, ankle joint, orthoses

Resumo - “Órtese semi-rígida e bandagem funcional diminuem a variabilidade do senso de posição da articulação do tornozelo." O presente estudo investigou o efeito da bandagem funcional e da órtese semi-rígida no senso de posição da articulação do tornozelo. Dezesseis mulheres saudáveis ( $20.8 \pm 2.3$ anos) posicionaram seus tornozelos ativamente nas posições alvo. As condições experimentais foram: 1) sem o uso de órtese, 2) com órtese semi-rígida de tornozelo e 3) com bandagem funcional. O erro absoluto (AE) e o erro variável (EV) foram calculados para a obtenção do senso de posição. Houve efeito da interação dos fatores condição e ângulo alvo somente para o $\mathrm{EV}$ obtido a $15^{\circ}$ de flexão plantar, cujos valores foram menores tanto com o uso de bandagem funcional, quanto com o uso de órtese semi-rígida. Pode-se concluir que o uso de dispositivos de tornozelo, seja bandagem funcional ou órtese semi-rígida, diminui a variabilidade do senso de posição da articulação do tornozelo a $15^{\circ}$ de flexão plantar, o que sugere uma possível diminuição do risco de ocorrência de entorse de tornozelo.

Palavras-chave: senso de posição, articulação do tornozelo, órteses

Resumen - “Órtesis semi-rígida y vendaje funcional reducen la variabilidad de la sensación de posición articular del tobillo." El objetivo del presente estúdio era poder conocer los efectos de los vendajes y de las tobilleras semi-rígidas en la sensación de posición articular de la articulación del tobillo. Dieciséis mujeres sanas (20,8 $\pm 2,3$ años) tomaron sus tobillos activamente en posiciones de destino. Las condiciones experimentales fueron: 1) sin usar ningún dispositivo ortopédico, 2) con órtesis semi-rígida, y 3) con vendaje funcional. Los errores absolutos (EA) y los errores variables (EV) fueron calculados para obtener la sensación de posición articular. Hubo un efecto de la interacción entre la condición y el ángulo de destino a $15^{\circ}$ flexión plantar sólo para el EV, el cual mostró menores errores en cuenta con vendaje funcional, como así también con la órtesis semi-rígida. En conclusión, el uso de órtesis de tobillo, ya sean la vendaje o bien órtesis semi-rígida, reducen la variabilidad de la sensación de posición articular a $15^{\circ}$ flexión plantar, lo que sugiere una posible disminución en el riesgo de esguince de tobillo.

Palabras clave: sensación de posición articular, la articulación del tobillo, órtesis 


\section{Introduction}

Proprioception is a complex somatossensorial modality that does not rely on visual information and it is responsible for the position sense of the limbs and the body. It is composed by skin, muscle, and joint receptors connected to neuroanatomic pathways (Gardner, Martin, \& Jessel, 2003; Kalish, Kattenstroth, Kowalewsk, Tegenthoff, \& Dinse, 2012; Smorenburg, Ledebt, Deconinck, \& Savelsbergh, 2011). According to Smorenburg et al. (2011) and Kalish et al. (2012), proprioception consists of two components: one responsible for identifying the position of the limb while moving (kinesthesia), and a second one responsible for identifying the position of the limb on static situations (position sense).

The integrity of structures responsible for proprioception allows correction of both movement and posture. Changes in the sensory information potentially affect movement control and consequently, functional tasks (Chaskel, Preis, \& Bertassoni, 2013; Gandevia, Smith, Crawford, Proske, \& Taylor, 2006).

Injuries that affect peripheral neural structures can impair the sense of limb and joint position, ultimately compromising posture (Pearson \& Gordon, 2003). Ankle sprain injuries potentially affect the sensory motor integration, which can have to serious consequences for an individual (e.g., loss of balance, gait disturbances, and functional incapacities) (Hughes \& Rochester, 2008; Janssen \& Kamper, 2013; Lin, Hiller, \& de Bie, 2010; van den Bekerom et al., 2012; Zinder, Granata, Shultz, \& Gansneder, 2009).

Ankle sprain is one of the most common injuries among athletes, corresponding to approximately $25 \%$ of all musculoskeletal injuries (Petersen et al., 2013; van den Bekerom et al., 2012). Most of ankle sprains occur during a joint inversion movement, mainly with the foot in plantar flexion, stretching the anterior talofibular ligament (van den Bekerom et al., 2012). In the presence of trauma due to sprains, mechanoreceptors of the involved structures are potentially affected, impairing proprioceptive information, and increasing joint instability (Barbanera, Araujo, Fernandes, \& Hernandez, 2012; Zinder et al., 2009). To prevent recurrence of joint sprain is crucial. The most effective strategy is to promote mechanical stability of the joint, which can be achieved by applying external prophylactic support, such as taping and bracing. These techniques promote mechanical stability and realignment of the ankle joint (Brandl, Abico, Grando, Domingos, \& Carvalho, 2013; Choukou \& Hijazi, 2013; Lees, 2001), decreasing the incidence of injury (Briem et al., 2011; Janssen \& Kamper, 2013; Kemler, van de Port, Backx, \& van Dijk, 2011; Lardenoye et al., 2012; Marcondes, Jesus, \& Gualberto, 2011; Silva \& Gonçalves, 2007).

Although proprioception and joint stability are closely related to each other, and prophylactic devices like taping and semi-rigid brace are widely used to enhance joint stability, the understanding of taping (and brace) and proprioception interaction can be further explored. The purpose of the present study is to investigate the effect of taping and semi-rigid ankle brace in the sense of the ankle joint position. We hypothesized that taping and semi-rigid ankle brace will enhance the precision of the position sense.

\section{Method}

\section{Participants}

Sixteen irregularly active women (age $=20.8 \pm 2$ years; body mass $=58 \pm 6 \mathrm{~kg}$; and height $=1.6 \pm 0.04$ meters) volunteered to participate in the present study. The volunteers were classified as inconsistently active, according to the International Physical Activity Questionary (IPAQ) (Pardini et al., 2001). Only women answered the invitation to participate in the study. By convenience, sixteen were selected. After a clinical evaluation of the ankle, those without history of lower limb fractures, ankle surgery or sprains in the past 12 months, and an inversion range of ankle motion higher than $30^{\circ}$ were selected to participate in the study. All volunteers signed an Informed Consent Form, previously approved by the Committee of Ethics and Research with Human Subjects of the São Judas Tadeu University, São Paulo, Brazil (\# 0062/2004).

\section{Experimental procedures}

Ankle joint passive positioning (pre-test) and active repositioning was chosen to test the sense of position via an isokinetic dynamometer (Biodex, System 3, EUA). Volunteers remained sitting, tied in the chair by belts with dynamometer attached to a knee $45^{\circ}$ flexed, and with distal support of the equipment around the foot, positioned at $90^{\circ}$ (leg foot angle, Figure 1).

Reaching-to-a-target movements were performed in a single plane of motion, in the sagittal plane for plantar flexion/extension, and in the coronal plane for pronation/ supination. Starting from a neutral position of the ankle joint, the target positions were set in: 1) supination at $10^{\circ}, 2$ ) supination at $\left.25^{\circ}, 3\right)$ plantar flexion at $15^{\circ}$, and 4) plantar flexion at $30^{\circ}$. Participants blindfolded during the

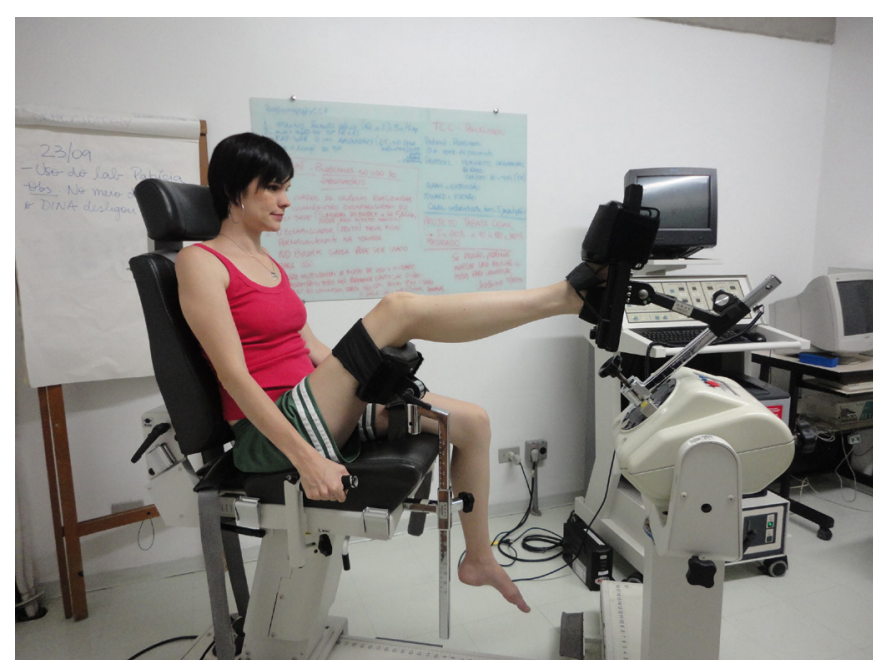

Figure 1. Positioning of the participant at the isokinetic dynamometer with the foot resting on the support plate of the equipment. 


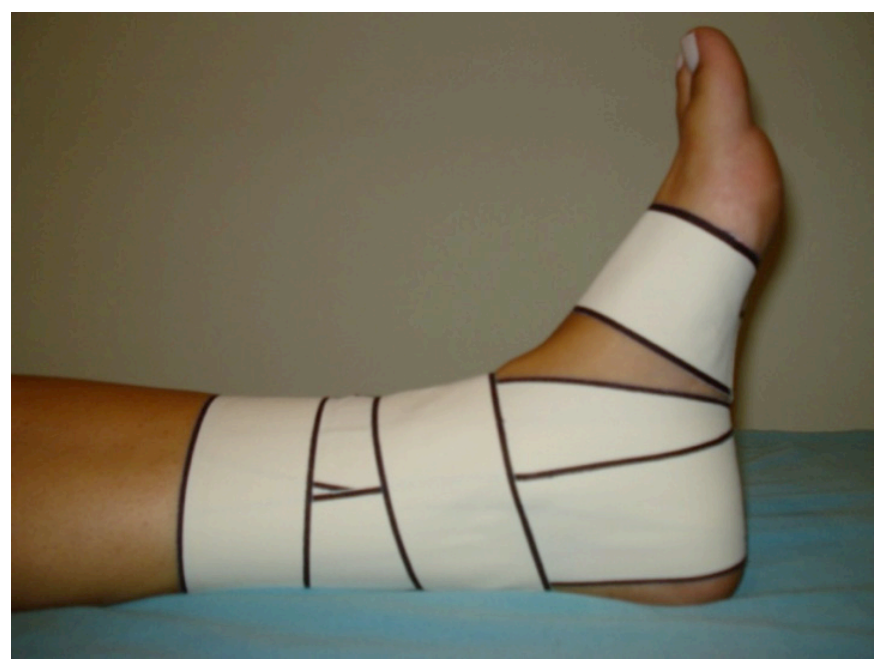

Figure 2. Technique used for taping application (medial view).

execution of the task. Before beginning the data collection, the volunteers were given sufficient time to adapt themselves to the experimental setup. Adaptation was assured by maintaining the joint in the targeted position for 10 seconds. This procedure was repeated as many times as necessary. After the adaptation period, position sense was measured. The protocol used to evaluate the position sense consisted of active movements performed at $10 \%$ s. This velocity was set in order to allow the dynamometer arm to be free for motion. All the volunteers performed the task in a velocity slightly slower than $10 \%$ s with no resistance coming from the machine. The order of the target angular position was randomly set. Three repetitions with a time interval of 20 seconds between the repetitions were performed for each of the four targets. Every three ankle movements, volunteers rested for 10 minutes while the target angle was set in the next position. The volunteers were instructed to press the locking device button (to record the angle) when they thought that they were at the target position. In one single session, the same evaluation was performed for each of the three experimental conditions, with a time interval of 15 minutes between them, in the following order: 1) no orthosis device, 2) wearing semi-rigid ankle bracing, and 3) wearing taping.

\section{Position sense variables}

Absolute error (AE) and variable error (VE) were calculated. According to Magill (2000), the AE is the absolute difference between real performance in the attempts and the goal. This value provides information regarding the performance error, which indicates a general index of precision. The same author defines VE as an error of performance which assesses the consistency (accuracy) for a series of trials. Together, these error-measures rate allow us to evaluate the performance in skills whose goal is action with precision and accuracy.

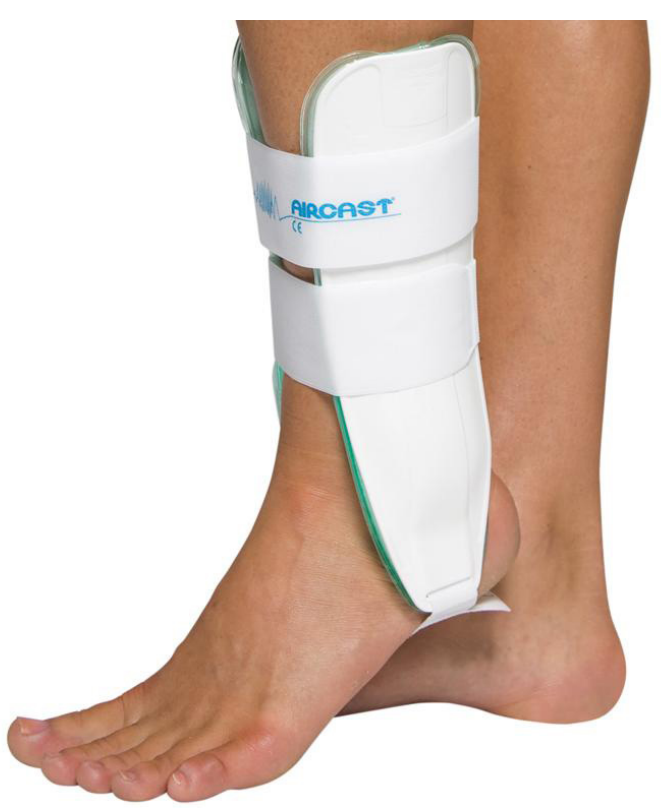

Figure 3. Semi-rigid brace used for ankle stabilization (Aircast Air Stirrup $\left.{ }^{\circledR}\right)$.

\section{Taping and semi-rigid brace}

Adhesive, inelastic, impermeable tapings (MISSNER ${ }^{\circledR}$ ) were cut in five centimeters wide strips. The strips' length was determined by the volunteers' leg length. The technique used for application is described by Poole and Poole (2004). An example of taping applied is illustrated in Figure 2 (A and B). For the semi-rigid ankle brace, we used an Aircast Air Stirrup ${ }^{\circledR}$ as illustrated in Figure 3.

\section{Statistical analysis}

A two-way $(3 \times 4)$ repeated measures analyses of variance (2-way ANOVA) was applied to compare each of the dependent variables (AE and $\mathrm{VE}$ ) in the conditions (no orthosis device/ wearing semi-rigid brace/ wearing taping) and for the target angles $\left(10^{\circ}\right.$ and $25^{\circ}$ of ankle supination, and $15^{\circ}$ and $30^{\circ}$ of plantar flexion). The Tukey post hoc test was used for multiple comparisons when the significance level was lower than 5\%.

\section{Results}

Data was tested for normality. The Kolmogorov-Smirnov test showed no significant difference from a normal distribution for each condition. The combination of target positions and orthosis devices did not affect the $\mathrm{AE}\left(\mathrm{F}_{(2,96)}=0.11 ; p=.89\right)$ and the $\operatorname{VE}\left(\mathrm{F}_{(2,96)}=0.03 ; p=.96\right)$ for the ankle joint position sense investigated in supination, nor the $\mathrm{AE}\left(\mathrm{F}_{(2.96)}=0.17 ; p=.84\right)$ measured in plantar flexion. However, the VE was significantly $\left(\mathrm{F}_{(2,96)}=3.78 ; p=.03\right)$ changed by the interaction between condition and target angle at $15^{\circ}$ of plantar flexion. Figure 4 illustrates $\mathrm{AE}$ and VE. 


\section{$\square$ taping $\square$ no orthotic device $\square$ semi-rigid brace}
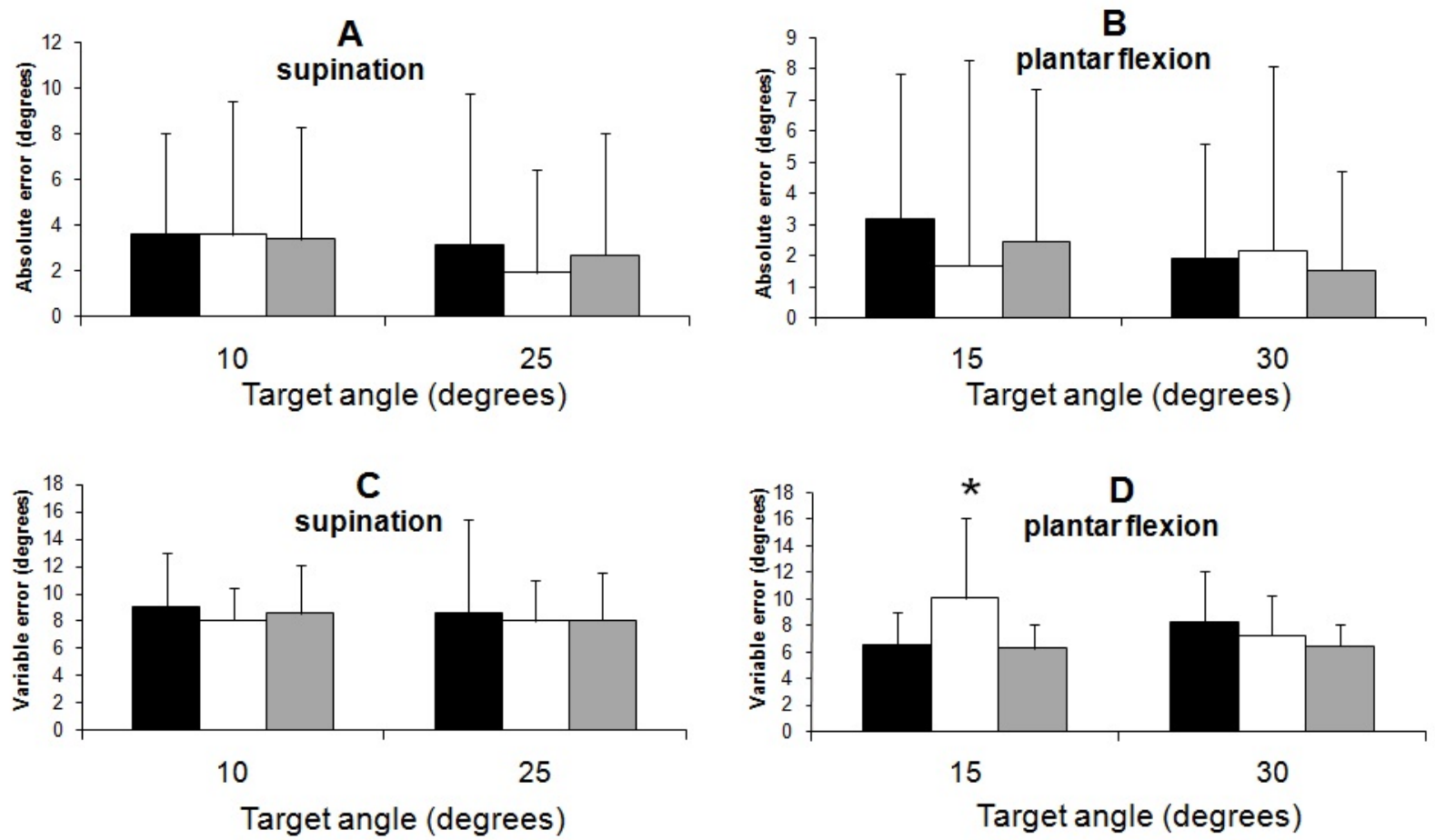

Figure 4. Mean (+ SD) Absolute error (AE) and variable error (VE) obtained during supination at $10^{\circ}$ and $25^{\circ}$ and during plantar flexion at $15^{\circ}$ and $30^{\circ}$. *Significantly higher than in the taping and semi-rigid ankle brace conditions $(n=16 ; p=.03)$.

\section{Discussion}

Most of ankle sprains occur in supination, which is a combination of plantar flexion, adduction, and inversion. Therefore, the lateral portion of the ankle is potentially affected (Janssen \& Kamper, 2013; van den Bekerom et al., 2012). Based on the ankle sprain injure mechanism, the present study investigated the effect of taping and semi-rigid ankle brace in the position sense evoked during active plantar flexion and ankle supination.

Although there are several studies on the topic, a great diversity exist on whether the orthosis device should be used, about the banding technique, and the target population. These aspects make a difficult situation for comparisons with our results. In the present study, the two orthosis devices more commonly used in real life situations were tested in the same sample. Moreover, the use of isokinetic dynamometer allowed the investigated uniplanar movement to be uniform. Although uniplanar movement has little ecological validity, it enables to measure the effect of the orthosis device separately in each joint motion direction.

Ankle orthoses are known to decrease the incidence of joint injures (Janssen \& Kamper, 2013; Kemler et al., 2011; Lardenoye et al., 2012; Marcondes et al., 2011). Although the main argument in favor of the use of orthoses is the mechanical external support provided (Choukou \& Hijazi, 2013), improved proprioception might explain part of the encouraging results. Some authors state that taping and semi-rigid brace not only promote an external support for mechanical effect, but they facilitate the activation of the proprioceptive components of the ankle joint structures (Briem et al., 2011; Kemler et al., 2011; Miralles et al., 2010; Zinder et al., 2009). Pearson and Gordon (2003) corroborate this hypothesis and highlight that proprioceptive components have their action optimized when there is an alignment of the body segments, facilitating synergistic action of the muscles involved.

Although ankle sprain usually results from passive movement, often occurs during conditions involving intense active joint movement and activation of muscles around the ankle, including agonistic and antagonistic. Such conditions are observed in sports in which side and cross-cutting maneuvers and/or jump landing are widely performed. In our experimental setup, testing the ankle joint position sense through actively reaching a target position might be considered more functional than doing it passively. Moreover, Lonn, Crenshaw, Djupsjobacka, Pedersen, and Johansson (2000) showed that the position sense of healthy volunteers does not differ when they reach the target position passively or actively, as long their joint is passively placed at the target position in the pre-test trial.

In the present study, the volunteers presented lower VE due to the use of orthoses, both taping and semi-rigid ankle brace, when the analyzed plantar flexion movement and the target were set at $15^{\circ}$. Interestingly, for larger amplitude $\left(30^{\circ}\right)$ the orthoses did not affect position sense. It is possible that the closer the ankle is to the neutral position, the better the feedback provided by the orthoses. This is the position where orthoses provides less mechanical resistance to a movement. As soon as the volunteers 
moved their foot further in plantar flexion, more resistance is applied by the orthoses, which indicates that little resistance means to be in a small range of joint motion and closer to the fifteen-degrees target position.

According to Pearson and Gordon (2003), motor efference is regulated by proprioception, which is influenced by the biomechanics of the body and the limbs. This results in movement coordination required to compensate intrinsic variability generated by the correction of the efferent stimuli. There are studies indicating that proprioception enhancement can be achieved by using joint orthoses. In a study performed with forty healthy volunteers, Miralles et al. (2010) found that taping meliorate ankle position sense at dorsiflexion, which is in accordance with the present study, showing that joint orthoses can affect sensory motor interactions. Based on the improvement of the proprioception provided by the external support, the authors argue that the orthoses assist in the treatment and prevention of ankle sprains as well. In a review of the literature, Cordova, Ingersoll and Palmiere (2002) found that external ankle support, taping and semi-rigid brace are able to improve proprioception.

Due to the use of taping during a controlled simulation of ankle sprain in inversion, increased motor unit recruitment of the peroneus longus muscle was demonstrated by Briem et al. (2011). This finding indicates changes in muscle activation caused by the external device during dynamic responses. The same study analyzed the use of elastic taping (kinesio tape) for the same condition. Elastic taping had no effect on muscle activation. The basic difference between inelastic and elastic taping is that the first has a mechanical effect on the joint, in addition to the increased afference of skin sensors due to tape -skin contact presented in both kinds of tape.

Although there are some studies investigating the effect of taping and semi-rigid brace on the ankle position sense and their clinical relevance, the neurophysiologic process that supports and explains changes in proprioception is not clearly understood. Moreover, the best experimental method to address this issue is not entirely established. Stability tests performed on unstable surfaces (Briem et al., 2011), 3-D kinematic analyses (Miralles et al., 2010), and dynamic tests (Bicici, S., Karatas, N., \& Baltaci, G., 2012) developed to grade ankle stability have been applied in an attempt to provide evidence of the benefits achieved with the use of ankle orthoses.

The hypotheses that taping and semi-rigid ankle brace enhance the position sense could not be confirmed. Even though the participants decreased variable error at $15^{\circ}$ of plantar flexion while using the orthotic devices, taping and semi-rigid ankle brace did not ameliorate absolute error of judging ankle joint position. The participants did not improve the sense of joint position; the orthotic devices made the judgment more accurate, but still not precise. Nevertheless, from the present study, it might be concluded that ankle joint orthotic devices (taping and semi-rigid brace) induce smaller variable errors at $15^{\circ}$ of plantar flexion, potentially decreasing ankle sprains occurrence.

The present study contributes to better understand the influence of ankle orthotic devices in proprioception. However, there are some issues that limit the present findings. The trials were performed only few minutes after the volunteers wore the orthoses. In real life the orthoses are used for hours, which potentially cause an adaptation to its use (Miralles et al., 2010). The number of volunteers and the population studied, women with no history of ankle sprain, might also have influenced the present results. It is known that the mechanoreceptors threshold is higher in chronic sprain ankle, which changes proprioception (Mebes et al., 2008; Paiva \& Silva, 2009; Silva, Silva, Sônego, $\&$ de Paula, 2011). Although there is much more still to be understood about the interaction between taping/semi-rigid ankle brace and ankle proprioception, the use of such devices aiming to prevent ankle joint sprains can be strongly recommended.

\section{References}

Barbanera, M., Araujo, R.C., Fernandes, T.D., \& Hernandez, A.J. (2012). Evaluation of the passive resistive torque in female athletes with ankle sprain. Revista Brasileira de Medicina do Esporte, 18, 112-6.

Bicici, S., Karatas, N., \& Baltaci, G. (2012). Effect of athletic taping and kinesiotaping ${ }^{\circledR}$ on measurements of functional performance in basketball players with chronic inversion ankle sprains. The International Journal of Sports Physical Therapy, 7, 154:66.

Brandl, L., Abico, R.M., Grando, F., Domingos, K.C., \& Carvalho, A.R. (2013). Influência da esparadrapagem na amplitude de movimento e na potência muscular de atletas de voleibol. Motriz, 19, S131.

Briem, K., Eythörsdöttir, H., Magnúsdóttir, R.G., Pálmarsson, R., Rúnarsdöttir, T., \& Sveinsson, T. (2011). Effects of kinesio tape compared with nonelastic sports tape and the untaped ankle during a sudden inversion perturbation in male athletes. The Journal of Orthopaedic and Sports Physical Therapy, 41(5), 328-35. doi:10.2519/jospt.2011.3501

Chaskel, C.F., Preis, C., \& Bertassoni, L.N. (2013). Propriocepção na prevenção e tratamento de lesões nos esportes. Revista Ciência \& Saúde, 6, 67-76.

Choukou, M.-A., \& Hijazi, S. (2013). Effectiveness of ankle taping on ankle joint kinematics during walking on level ground. Foot \& Ankle Specialist, 6, 352-355. doi:10.1177/1938640013501547

Cordova, M.L., Ingersoll, C.D., \& Palmieri, R.M. (2002). Efficacy of Prophylactic Ankle Support: An Experimental Perspective. Journal of Athletic Training, 37, 446-457. Retrieved from http:// www.pubmedcentral.nih.gov/articlerender.fcgi?artid=164376\&tool $=$ pmcentrez\&rendertype $=$ abstract

Gandevia, S.C., Smith, J.L., Crawford, M., Proske, U., \& Taylor, J.L. (2006). Motor commands contribute to human position sense. The Journal of Physiology, 571, 703-710. doi:10.1113/jphysiol.2005.103093

Gardner, E.P., Martin, J.H., \& Jessel, T.M. (2003). As Sensações Corporais. In E.R. Kandel, J.H. Schwartz, and T.M. Jessell (Eds), Principios da Neurociência (pp. 430-50, 4a ed.) São Paulo: Manole.

Hughes, T., \& Rochester, P. (2008). The effects of proprioceptive exercise and taping on proprioception in subjects with functional ankle instability: a review of the literature. Physical Therapy in Sport: Official Journal of the Association of Chartered Physiotherapists in Sports Medicine, 9, 136-47. doi:10.1016/j.ptsp.2008.06.003

Janssen, K.W., \& Kamper, S.J. (2013). Ankle taping and bracing for proprioception. British Journal of Sports Medicine, 47, 527-528. doi:10.1136/bjsports-2012-091836

Kalish, T., Kattenstroth, J.C., Kowalewsk, R., Tegenthoff, M., \& Dinse, H.R. (2012). Age-related change in the joint position sense of the human hand. Clinical Intervention in Aging, 7, 499-507. 
Kemler, E., van de Port, I., Backx, F., \& van Dijk, C.N. (2011). A systematic review on the treatment of acute ankle sprain: brace versus other functional treatment types. Sports Medicine, 41, 185-197. doi: 10.2165/11584370-000000000-00000.

Lardenoye, S., Theunissen, E., Cleffken, B., Brink, P.R., de Bie, R., \& Poeze, M. (2012). The effect of taping versus semi-rigid bracing on patient outcome and satisfaction in ankle sprains: a prospective, randomized controlled trial. BMC Musculoskeletal Disorders, 13, 81. doi:10.1186/1471-2474-13-81

Lees, A. (2001). Biomechanics of soccer. Motriz, 7, S19-28.

Lin, C.-W. C., Hiller, C.E., \& de Bie, R. A. (2010). Evidence-based treatment for ankle injuries: a clinical perspective. The Journal of Manual \& Manipulative Therapy, 18, 22-28. doi:10.1179/10669 8110X12595770849524

Lonn, J., Crenshaw, A.G., Djupsjobacka, M., Pedersen, J., \& Johansson, H. (2000). Position sense testing: influence of starting position and type of displacement, Archives of Physical Medicine and Rehabilitation, 81, 592-597.

Magill, R.A. (2000). Introdução às habilidades motoras. In R.A. Magill (Ed), Aprendizagem Motora: Conceitos e Aplicações. (pp. 83-88, 5a ed.). São Paulo: Edgard Blucher.

Marcondes, F.B., Jesus, J.F., \& Gualberto, H.D. (2011). The use of rigid adhesive bandage (taping) in the improvement of proprioceptive sensibility of the foot and ankle: a systematic review. Medicine \& Rehabilitation, 30, 18-21.

Mebes, C., Amstutz, A., Luder, G., Zizwiler, H.R., Stettler, M., Villiger, P.M.,... Radlinger, L. (2008). Isometric rate of force development, maximum voluntary contraction, and balance in women with and without joint hypermobility. Arthritis \& Rheumatology, 59, $1665-1669$.

Miralles, I., Monterde, S., Montull, S., Salvat, I., Fernández-Ballart, J., \& Beceiro, J. (2010). Ankle taping can improve proprioception in healthy volunteers. Foot \& Ankle International / American Orthopaedic Foot and Ankle Society [and] Swiss Foot and Ankle Society, 31, 1099-1106. doi:10.3113/FAI.2010.1099

Paiva, T.M. \& Silva, T.C.D. (2009). A correlação entre hipermobilidade articular e escoliose idiopática em mulheres. Fisioterapia em Movimento, 22, 77-85.

Pardini, R., Matsudo, S., Araújo, T., Matsudo, V., Andrade, A., Braggion, G.,... Raso, V. (2001). Validação do questionário internacional de nível de atividade física (IPAQ - versão 6): estudo piloto em adultos jovens brasileiros. Revista Brasileira de Ciência e Movimento, 9, 45-51.

Pearson, K., \& Gordon, J. (2003). Os Reflexos Espinais. In E.R. Kandel, J.H. Schwartz, and T.M. Jessell (Eds), Princípios da Neurociência (pp. 713-35, 5a ed.). São Paulo: Manole.

Petersen, W., Rembitzki, I.V., Koppenburg, A.G., Ellermann, A., Liebau, C., Brüggemann, G.P., \& Best, R. (2013). Treatment of acute ankle ligament injuries: a systematic review. Archives of Orthopaedic and Trauma Surgery, 133, 1129-1141. doi:10.1007/ s00402-013-1742-5

Poole, R.M.B., \& Poole, J.M. (2004). Taping Procedures for Athletic Competition. In R.B. Birrer and F.G. O'Connor (Eds), Sports medicine for the primary care physician (pp. 359-70, $3^{\text {rd }}$ ed.). United States: CRCPress.
Silva, P.B., \& Gonçalves, M. (2007). Suportes de pé e tornozelo: efeitos na biomecânica e na prevenção de lesões desportivas. Motriz, $13,312-23$

Silva, R.S., Silva, A.P., Sônego, D.A., \& de Paula, N.M. (2011). Alterações neuromusculares no quadril associadas a entorse do tornozelo: revisão de literatura. Fisioterapia em Movimento, 24, 503-11.

Smorenburg, A.R., Ledebt, A., Deconinck, F.J., \& Savelsbergh, G.J. (2011). Visual feedback of the non-moving limb improves active joint position sense of the impaired limb in spastic hemiparetic cerebral palsy. Research in Developmental Disabilities, 32, 1107-1116.

Van den Bekerom, M.P.J., Struijs, P., Blankevoort, L., Welling, L., van Dijk, C.N., \& Kerkhoffs, G.M.M.J. (2012). What is the evidence for rest, ice, compression, and elevation therapy in the treatment of ankle sprains in adults? Journal of Athletic Training, 47, 435-443. doi:10.4085/1062-6050-47.4.14

Zinder, S.M., Granata, K P., Shultz, S.J., \& Gansneder, B.M. (2009). Ankle bracing and the neuromuscular factors influencing joint stiffness. Journal of Athletic Training, 44, 363-369. doi:10.4085/10626050-44.4.363

\section{Authors' note}

Márcia Barbanera (marciabarbanera@hotmail.com), Flávia de Andrade e Souza Mazuchi (flavia.ft@hotmail.com), José Paulo Berretta Batista (jp.fisio@hotmail.com), Janaina de Moura Ultremare (janaultre@ yahoo.com.br), and Juliana da Silva Iwashita (juli_iwashita@yahoo. com.br) are affiliated with the Laboratory of Biomechanics Human Movement, São Judas Tadeu University, São Paulo, Brazil.

Ulysses Fernandes Ervilha (ulyervil@usp.br) is affiliated with the School of Arts, Sciences and Humanities, University of São Paulo, São Paulo, Brazil.

\section{Corresponding author}

Márcia Barbanera

Rua Dias Leme, 134, ap. 23, Mooca São Paulo SP 03118-040, Brazil Phone: 2799-1659 - Fax: 5511 3069-6908

E-mail: marciabarbanera@hotmail.com

Manuscript submitted on February 27, 2014

Manuscript accepted on September 11, 2014

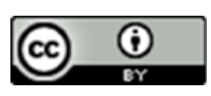

Motriz. The Journal of Physical Education. UNESP. Rio Claro, SP, Brazil - eISSN: 1980-6574 - under a license Creative Commons - Version 3.0 